Disclosure of Interest: None declared

DOI: 10.1136/annrheumdis-2017-eular.5109

\section{AB0984 TOCILIZUMAB MONOTHERAPY FOR POLYMYALGIA RHEUMATICA RESULTS OF 52-WEEK TREATMENT OF A PROSPECTIVE, SINGLE-CENTER, OPEN, SINGLE-ARM TRIAL}

K. Amano, K. Chino, Y. Okada, A. Shibata, A. Okuyama, T. Kurasawa, H. Takei, T. Kondo. Rheumatology and clinical immunology, Saitama Medical Center, Saitama Medical University, Kawagoe, Japan

Background: Polymyalgia rheumatic (PMR) is a chronic inflammatory rheumatic disease in the elderly people. Glucocorticoid (GC) is still definitely a mainstay for the treatment of PMR, but long-term GC therapy is a major risk factor of osteoporotic fractures, diabetes, hyperlipidemia, cardio-cerebral vascular events, glaucoma, etc. So GC-free treatment strategies for PMR are necessary for some patients with PMR. IL-6 is involved in the pathogenesis of PMR and quite a few case reports have already shown the efficacy of tocilizumab (TCZ) in PMR patients and some of them received TCZ monotherapy without GC.

Objectives: To assess the efficacy and safety of TCZ monotherapy for PMR Methods: Thirteen PMR patients (male 3, female 10) who had been diagnosed by 2012 ACR/EULAR classification criteria from Jan 2013 to Feb 2015 were enrolled in our study (IRB application No. 638, UMIN registration No. 000008812) after obtaining the written informed consent. TCZ $(8 \mathrm{mg} / \mathrm{kg})$ was administered biweekly for the first 2 months (5 infusions) and every 4 weeks thereafter for 40 weeks (total 48 weeks). ESR, CRP, patient's global health assessed by visual analog scale (VAS), PMR activity score were evaluated every 4 week prospectively and were evaluated at week 52. Remission was defined as PMR activity score less than 1.5.

Results: Baseline patients' characteristics revealed various kinds of comorbidities in 11 patients; hypertension in 7 , hyperlipidemia in 5 , diabetes mellitus in 3 , osteoporotic vertebral fractures in 2 , history of angina pectoris in 1, history of brain infarction in 1, history of hematemesis due to NSAID ulcer in 1 and glaucoma in one patient. Nine patients could complete this 52-week trial and could achieve remission at week 52 . Two patients discontinued TCZ because of no response at week 6 (No.1) and week 16 (No. 8) respectively. One patient (No.2), who were in clinical remission of PMR, dropped out from this study due to pemphigoid at week 50 and received GC therapy. Patient No. 12 abandoned TCZ at week 12 because of lung infiltrates although she was treated successfully with TCZ monotherapy, and she had been in remission without any treatment until week 52 . The other 3 drop-out patients could obtain remission with GC therapy at week 52 . There were no serious adverse events during 52-week treatment period.

Conclusions: TCZ mono-therapy was effective in most (9 out of 13) PMR patients although response was not so rapid as compared to GC. TCZ mono-therapy may be a good alternative therapy instead of GC for elderly patients with various comorbidities

\section{References:}

[1] Unizony S, et al.: Arthritis Care Res 2012; 64(11):1720-1729.

[2] Macchioni P, et al.: Aemin Arthritis Rheum 2013; 43(1): 113-118.

[3] Toussirot E, et al.: J Rheumatol 2016 43(1): 249-251.

[4] Leeb BF, et al.: Arthritis Rheum 2007; 57(5): 810-815.

Acknowledgements: We will thank Izumi Oshima, Takashi Kukita for data collection and management of this study.

Disclosure of Interest: K. Amano Grant/research support from: Chugai Pharnmaceutical Co.Ltd., K. Chino: None declared, Y. Okada: None declared, A. Shibata: None declared, A. Okuyama: None declared, T. Kurasawa: None declared, H. Takei: None declared, T. Kondo: None declared

DOI: 10.1136/annrheumdis-2017-eular.4525

\section{AB0985 METHOTREXATE AS INDUCTION OF REMISSION THERAPY FOR LOCALIZED MANIFESTATIONS OF IGG4-RELATED DISEASE}

L. Rovati $^{1}$, E. Della-Torre ${ }^{1}$, M. Lanzillotta ${ }^{1}$, E. Bozzalla Cassione ${ }^{1}$, E. Bozzolo ${ }^{1}$ C. Canevari ${ }^{2}$, M. Falconi ${ }^{3,4}$, L. Dagna ${ }^{1,4} .{ }^{1}$ Unit of Immunology, Rheumatology, Allergy and Rare Diseases; ${ }^{2}$ Unit of Nuclear Medicine; ${ }^{3}$ Pancreatic Surgery Unit, San Raffaele Scientific Institute; ${ }^{4}$ Università Vita-Salute San Raffaele, Milan, Italy

Background: Medium to high dose glucocorticoids represents the treatment of choice for inducing remission in IgG4-related disease (IgG4-RD) patients ${ }^{1}$. However, clinicians might prefer alternative equally effective drugs in clinical settings where long-term corticosteroids treatment is contraindicated, such as diabetes or osteoporosis. We recently reported the efficacy of methotrexate in maintaining glucocorticoids induced lgG4-RD remission ${ }^{2}$.

Objectives: To evaluate the efficacy of methotrexate as induction of remission therapy in selected cases of mild and localized IgG4-RD complicated by clinical scenarios that might advise against corticosteroids treatment.

Methods: Five patients with active untreated IgG4-RD were started on oral or subcutaneous methotrexate (up to 15-20 mg/week). Efficacy of methotrexate in inducing remission was assessed at 6 months by $18 \mathrm{~F}$-FDG PET/CT scan and by measuring the IgG4-RD Responder Index (RI) ${ }^{3}$ and circulating plasmablasts ${ }^{4}$. Partial response (PR) corresponded to an improvement of the IgG4-RD RI >2 points. Complete response (CR) corresponded to an IgG4-RD RI score $<3$.
Results: All patients were males with a mean age of 67 years (range 53-78). Two had pancreatic involvement; one had lymph node enlargement; one had pancreatic and lymph node involvement; one had pancreatic, aortic, submandibular gland and lymph node involvement. Patients with pancreatic involvement presented with increased serum amylases or abdominal discomfort; none had obstructive jaundice; all had overt diabetes. The mean IgG4-RD RI, serum IgG4 concentration and plasmablasts counts at baseline were $8(6-15), 483 \mathrm{mg} / \mathrm{dL}(136-983)$ and $3336 / \mathrm{mL}$ (330-9330/mL), respectively. All patients had increased $18 \mathrm{~F}-\mathrm{FDG}$ uptake on PET/CT scan within the affected organs. After 6 months of methotrexate, Patients 1, 2, and 3 were on CR with improved or normalized PET/CT findings, serum IgG4 and plasmablasts levels. Patient 5 achieved PR, showing improved 18F-FDG-PET/CT findings, normal plasmablasts level, but stable serum IgG4 concentration; after 10 months of methotrexate, persistence of disease activity prompted the introduction of glucocorticoids. Methotrexate was stopped in Patient 4 after 5 months because of nausea and vomiting; at 6 months he showed persistently increased plasmablasts count and 18F-FDG uptake on PET/CT, thus requiring a rescue therapy with glucocorticoids. (Table 1)

\begin{tabular}{|c|c|c|c|c|c|c|}
\hline & \multirow{2}{*}{\multicolumn{2}{|c|}{$\begin{array}{c}\text { Pationt } n 1(M, 78) \\
\text { Type } 1 \text { AAP, artic, submandibular } \\
\text { gland, lymph node involvement }\end{array}$}} & \multicolumn{2}{|c|}{ Patient $12(M, 67)$} & \multicolumn{2}{|c|}{ Patient $\pi 3(M, 70)$} \\
\hline & & & \multicolumn{2}{|c|}{ Type 1 AlP } & \multicolumn{2}{|c|}{$\begin{array}{l}\text { Type } 1 \text { Aip, iymph node } \\
\text { involvement }\end{array}$} \\
\hline & $\begin{array}{l}\text { Pre. } \\
\text { Treatment }\end{array}$ & $\begin{array}{c}6 \text { months (MTx } 20 \\
\mathrm{me} / \text { week) }\end{array}$ & Pre-Treatment & $\begin{array}{l}6 \text { months } \\
\text { (MTX15 } 15 \\
\text { me/week) }\end{array}$ & Pre-Treatment & $\begin{array}{l}6 \text { months } \\
\text { (MTR } 15 \\
\text { me/week) }\end{array}$ \\
\hline IgGA-RD RI & 15 & $2(C R)$ & 6 & $2(C R)$ & 9 & $1(C R)$ \\
\hline $\lg G 4(\mathrm{mg} / \mathrm{dl})$ & 498 & 313 & 586 & 324 & 221 & 157 \\
\hline PBSS/mL & 2520 & 250 & 940 & 470 & 3560 & 130 \\
\hline \multirow[t]{4}{*}{ 18F-FDG-PET/CT } & $\begin{array}{l}\text { Increased } \\
\text { FDG activity } \\
\text { in all affected } \\
\text { Organs except } \\
\text { Dancreas }\end{array}$ & $\begin{array}{l}\text { Decreased FDG } \\
\text { xctivity in } \\
\text { subrandibulat } \\
\text { glands; negative in } \\
\text { all the octher organs }\end{array}$ & $\begin{array}{l}\text { Increased FDG } \\
\text { activity in } \\
\text { pancreatic chead } \\
\text { and tail }\end{array}$ & $\begin{array}{l}\text { Partial } \\
\text { reduction in } \\
\text { ppanceatic } \\
\text { FDG activity }\end{array}$ & $\begin{array}{l}\text { Increased FDG } \\
\text { activity in } \\
\text { pancreas and } \\
\text { hilar Iymph } \\
\text { nodes }\end{array}$ & $\begin{array}{l}\text { Negative in all } \\
\text { the involved } \\
\text { organs }\end{array}$ \\
\hline & \multicolumn{2}{|c|}{ Patient $n 4(M, 61)$} & \multicolumn{2}{|c|}{ Patient $45(M, 53)$} & & \\
\hline & \multicolumn{2}{|c|}{ Type 1 AlP } & \multicolumn{2}{|c|}{ Lymph node involvement } & & \\
\hline & Pre-Treatment & $\begin{array}{l}6 \mathrm{months} \text { (MTX } \\
15 \mathrm{mg} / \text { week) }\end{array}$ & $\begin{array}{l}\text { Pre. } \\
\text { Treatment }\end{array}$ & $\begin{array}{l}2 \text { months (MTX } \\
20 \mathrm{~m} / \text { week) }\end{array}$ & & \\
\hline IGGA-RD RI & 6 & NA & 6 & $3(\mathrm{PR})$ & & \\
\hline $\operatorname{lgGA}(\mathrm{mg} / \mathrm{dL})$ & 136 & NA & 973 & 819 & & \\
\hline PBS/mL & 330 & 880 & 9330 & 0 & & \\
\hline 18F-FDG-PET/CT & $\begin{array}{l}\text { Increased FDG } \\
\text { activity in } \\
\text { pancreatic head } \\
\text { and body }\end{array}$ & $\begin{array}{l}\text { Markedly } \\
\text { increased FDG } \\
\text { activity in } \\
\text { pancreati head } \\
\text { and body }\end{array}$ & $\begin{array}{l}\text { Increased } \\
\text { nodal FDG } \\
\text { activity }\end{array}$ & $\begin{array}{l}\text { Decreased } \\
\text { nodal FDG } \\
\text { ctivity, but not } \\
\text { dimensional } \\
\text { eduction of the } \\
\text { lymph nodes }\end{array}$ & & \\
\hline
\end{tabular}

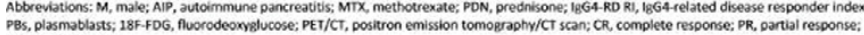
PBS, plasmablasts;
NA. not avoliable.

Conclusions: In localized forms of IgG4-RD with mild manifestations, methotrexate represents a promising alternative strategy for inducing disease remission, especially in the presence of contraindications to glucocorticoids.

References:

[1] Khosroshahi A, et al. International Consensus Guidance Statement on the Management and Treatment of IgG4-Related Disease. Arthritis Rheumatol. 2015.

[2] Della-Torre E, et al. Methotrexate for maintenance of remission in IgG4-related disease. Rheumatology (Oxford). 2015.

[3] Carruthers MN, et al. Development of an IgG4-RD Responder Index. Int J Rheumatol. 2012.

[4] Wallace ZS, et al. Plasmablasts as a biomarker for IgG4-related disease, independent of serum IgG4 concentrations. Ann Rheum Dis. 2015.

Disclosure of Interest: None declared

DOI: 10.1136/annrheumdis-2017-eular.4499

\section{AB0986 FAMILY MEDITERRANEAN FEVER GENE MUTATIONS: A POORLY STUDIED CAUSE OF INTERMITTENT HYDRARTROSIS}

M. Espinosa Malpartida ${ }^{1}$, C. Barbadillo Mateos ${ }^{1}$, C. Ramos Giraldez ${ }^{1}$,

B.J. Flores Robles ${ }^{1}$, E. González Vioque ${ }^{2}$, C. Merino Argumanez ${ }^{1}$, M. Jimenez Palop ${ }^{1}$, J. Sanz Sanz ${ }^{1}$, H. Godoy Tundidor ${ }^{1}$, J. Campos Esteban ${ }^{1}$, J.L. Andreu Sanchez ${ }^{1}$, L.F. Villa Alcazar ${ }^{1}$, J. Mulero Mendoza ${ }^{1} .{ }^{1}$ Rheumatology;

${ }^{2}$ Biochemistry, Hospital Universitario Puerta de Hierro Majadahonda, Madrid, Spain

Background: Familial Mediterranean Fever (FMF) is an inherited autoinflammatory disorder caused by mutations in the MEFV gene encoding pyrine, characterized by recurrent episodes of fever and serositis. Some patients with FMF present incomplete penetrance of the disease and may manifest only as intermittent arthritis.

Objectives: Characterization of musculoskeletal clinical manifestations in patients with mutations of the MEFV gene in our hospital.

Methods: We retrospectively reviewed clinical records of patients with mutations detected in the Family Mediterranean Fever MEFV gene in our hospital from January 1, 2008 to October 1, 2016. We collected parameters such as age at diagnosis, age of onset Of the symptoms, sex, affected joints, other extra-articular manifestations and type of MEFV gene mutation. 